\title{
Analysis of mitochondrial protein synthesis: de novo translation, steady-state levels, and assembled respiratory chain complexes
}

\begin{tabular}{|c|c|}
\hline Journal: & Current Protocols \\
\hline Manuscript ID & CP-18-0041.R1 \\
\hline Wiley - Manuscript type: & Protocol \\
\hline Date Submitted by the Author: & 06-Apr-2018 \\
\hline Complete List of Authors: & $\begin{array}{l}\text { Hilander, Taru; University of Helsinki, Research Program for Molecular } \\
\text { Neurology } \\
\text { Konovalova, Svetlana; University of Helsinki, Research Program for } \\
\text { Molecular Neurology } \\
\text { Terzioglu, Mugen; University of Helsinki, Research Program for Molecular } \\
\text { Neurology } \\
\text { Tyynismaa, Henna; University of Helsinki, Research Program for Molecular } \\
\text { Neurology }\end{array}$ \\
\hline Keywords: & proteostasis, mitochondria, protein synthesis, OXPHOS complexes \\
\hline Abstract: & $\begin{array}{l}\text { Mitochondria are multifunctional organelles with their own genome and } \\
\text { protein synthesis machinery. The } 13 \text { proteins encoded by mitochondrial } \\
\text { DNA (mtDNA) are core subunits of the oxidative phosphorylation } \\
\text { (OXPHOS) system producing the majority of cellular ATP. Yet most } \\
\text { mitochondrial proteins are encoded by nuclear genes, synthesized by } \\
\text { cytosolic ribosomes and imported into mitochondria. Therefore, } \\
\text { disturbances in cytosolic proteostasis have consequences on the gene } \\
\text { expression and synthesis of mtDNA-encoded proteins and overall on } \\
\text { mitochondrial function. Internal and environmental factors such as } \\
\text { mutations, aging, oxidative stress and toxic agents can affect the } \\
\text { translation and the stability of mitochondrial proteins and lead to OXPHOS } \\
\text { dysfunction. Here we describe methods for analysis of mitochondrial } \\
\text { translation rate and protein stability using radioactive and non-radioactive } \\
\text { technique as well as the methods for studying steady state levels and } \\
\text { assembly of OXPHOS complexes. }\end{array}$ \\
\hline
\end{tabular}




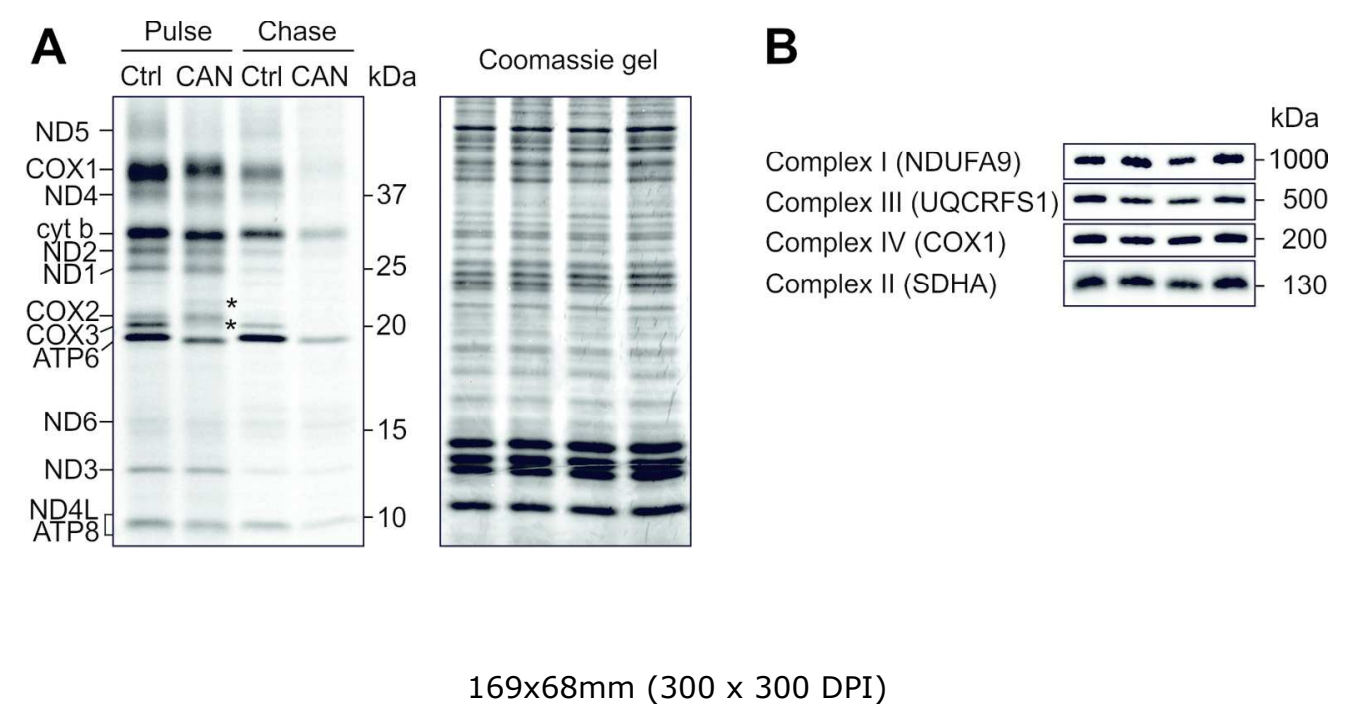




\title{
TEMPLATE for PROTOCOL UNIT
}

\section{Analysis of mitochondrial protein synthesis: de novo translation, steady-state levels, and assembled OXPHOS complexes}

Taru Hilander ${ }^{1}$, Svetlana Konovalova ${ }^{1}$, Mügen Terzioglu and Henna Tyynismaa ${ }^{*}$

Research Programs Unit, Molecular Neurology, University of Helsinki, 00290 Helsinki, Finland

${ }^{1}$ These authors contributed equally and should be considered co-first authors

*Correspondence should be addressed to Henna Tyynismaa, Biomedicum Helsinki, r.C520b, Haartmaninkatu 8, 00290 Helsinki, Finland. Tel: +358 2941 25654; Email:

henna.tyynismaa@helsinki.fi

\section{Significance Statement}

Mitochondria are organelles that play a key role in energy production in our cells. They use oxidative phosphorylation for producing ATP. Mitochondria have their own genome and protein synthesis for producing the core protein components of the oxidative phosphorylation system. The protocols described here are for investigating the production and stability of these core proteins and the oxidative phosphorylation complexes in mitochondria of cultured cells.

\begin{abstract}
Mitochondria are multifunctional organelles with their own genome and protein synthesis machinery. The 13 proteins encoded by mitochondrial DNA (mtDNA) are core subunits of the oxidative phosphorylation (OXPHOS) system producing the majority of cellular ATP. Yet most mitochondrial proteins are encoded by nuclear genes, synthesized by cytosolic ribosomes and imported into mitochondria. Therefore, disturbances in cytosolic proteostasis have consequences on the gene expression and synthesis of mtDNA-encoded proteins and overall on mitochondrial function. Internal and environmental factors such as mutations, aging, oxidative stress and toxic agents can affect the translation and the stability of mitochondrial proteins and
\end{abstract}


lead to OXPHOS dysfunction. Here we describe methods for analysis of mitochondrial translation rate and protein stability using radioactive and non-radioactive technique as well as the methods for studying steady state levels and assembly of OXPHOS complexes.

Keywords: proteostasis, mitochondria, protein synthesis, OXPHOS complexes

\section{INTRODUCTION}

Mitochondria are multifunctional organelles requiring the input of two genomes and two protein synthesis machineries (Hallberg and Larsson, 2014; Nunnari and Suomalainen, 2012; Hilander et al., 2018). Mammalian mitochondrial ribosomes produce 13 core protein subunits of the oxidative phosphorylation (OXPHOS) complexes, which are responsible for the production process of most cellular ATP. These 13 proteins are encoded by mitochondrial DNA (mtDNA), as well as the 22 tRNAs and 2 rRNAs involved in their synthesis. The rest of the mitochondrial proteome, about 1500 proteins, is encoded by the nuclear genome, synthesized by cytosolic ribosomes, and imported into mitochondria. The imported proteins include all protein components of the mitochondrial gene expression and protein synthesis machinery, such as the aminoacyl-tRNA synthetases and mitoribosomal proteins, as well as the rest of OXPHOS complex subunits. Thus, mutations either in mitochondrial or in nuclear genes can cause defects in mitochondrial translation and in the function of OXPHOS complexes.

As the imported mitochondrial proteins must be first synthesized in the cytosol, disturbances in cytosolic proteostasis may also have severe consequences for mitochondrial OXPHOS function, and also for other functions of the mitochondria for example in anabolic processes and regulation (D'Amico et al., 2017). For example, the incorporation of arginine analog canavanine into newly synthesized proteins causes major protein misfolding in cytosol and protein instability in mitochondria, which both contribute to a severe OXPHOS defect (Konovalova et al., 2015). In relation to the bacterial origin of mitochondria, some antibiotics such as tetracycline also disturb the mitochondrial protein synthesis (Moullan et al., 2015).

As methods to study mitochondrial protein translation and the stability of OXPHOS complexes we recommend to use in vivo mitochondrial translation assays and blue -native PAGE (BN-PAGE) of assembled OXPHOS complexes. For the in vivo mitochondrial translation assay, cells are grown with radioactively labeled amino acids, while simultaneously blocking the cytosolic protein translation with antibiotics such as anisomycin or emetine. This enables the labeling of the proteins synthesized by mitoribosomes only. With a short pulse of radioactively labeled amino acids, the translation rate of the 13 mtDNA encoded proteins can be evaluated. By washing the extra label away from the cells, followed by a chase period, the stability of the proteins can be estimated. This method is a powerful tool to study the function of the entire translation process in mitochondria. We have also utilized a puromycin-based non-radioactive method for testing mitochondrial translation rate (Konovalova et al., 2015), which was previously successfully applied for analysis of protein translation rate in cytoplasm (Schmidt et al., 2009; Miyamoto-Sato et al., 2000). 
By BN-PAGE, the assembly and stability of the entire OXPHOS complexes can be evaluated. First, mitochondria are extracted from cells or tissues, after which the OXPHOS complexes are extracted in native state from the mitochondria and run on a native gel.

When testing the effect of a transient stress on the stability of the OXPHOS complexes and their subunits, it may be necessary to block the mitochondrial translation for example with an antibiotic chloramphenicol before the stress treatment, because the lifetime of OXPHOS subunits and the entire complexes can be more than 48 hours in cultured cells, and therefore the effects of the stress cannot be easily detected. In such cases we have depleted the OXPHOS complexes by chloramphenicol for 48 hours and followed the recovery of the complexes or their subunits under the stress treatment (Konovalova et al., 2015).

\section{BASIC PROTOCOL 1}

\section{IN VIVO MITOCHONDRIAL TRANSLATION ASSAY}

The purpose of this assay is to study the translation rate and stability of the 13 mtDNA encoded proteins by using radioactively labeled amino acids simultaneously with a blocker of cytoplasmic protein translation. The following protocol is modified from (Fernandez-Silva et al., 2007).

\section{Materials}

Cultured adherent cells

Cell culture medium (for example: DMEM (Lonza Cat\# 12-614F/12), 10\% FBS (Life Technologies Cat\# 10270106), 1\% Penicillin Streptomycin (Lonza Cat\# 17-602E), 1\% L-glutamine (Life Technologies Cat\# 25030024))

Labeling medium (cell culture medium without methionine and cysteine). For labeling media use DMEM without methionine and cysteine (Life Technologies Cat\# 21013024) and dialyzed FBS (Life Technologies Cat\# 26400036).

PBS (Life Technologies Cat\# BE17-516F)

Inhibitor of cytoplasmic protein translation, emetine or anisomycin (see recipe)

${ }^{35} \mathrm{~S}$-methionine or mixture of ${ }^{35} \mathrm{~S}$-methionine and ${ }^{35} \mathrm{~S}$-cysteine (for example EXPRE35S Protein Labeling Mix from Perkin- Elmer Cat\# NEG072007MC). Pure ${ }^{35}$ S-methionine gives the strongest signal and the best signal/noise ratio, but the mixture of methionine and cysteine is less expensive and the signal intensity is about $75 \%$ compared to the methionine only) Protease inhibitors (Thermo Scientific Cat\# 10137963)

Protein assay kit (Bradford, BioRad Cat\# 5000006)

40\% Acrylamide/Bis 37.5:1 (Bio-Rad Cat\# 161-0148)

$1.5 \mathrm{M}$ Tris-HCl pH 8.8 (Tris base (Fisher BioReagents Cat\# BP152))

$1 \mathrm{M}$ Tris- $\mathrm{HCl}$ pH 6.8 (Tris base (Fisher BioReagents Cat\# BP152))

$\mathrm{ddH}_{2} \mathrm{O}$

100\% Glycerol (Sigma Cat\# G5516)

20\% SDS (Fisher Cat\# 10607443)

10\% Ammonium persulfate (Sigma Cat\# A3678) 
$\mathrm{N}, \mathrm{N}, \mathrm{N}^{\prime}, \mathrm{N}^{\prime}$-Tetramethylethylenediamine (TEMED) (Sigma Cat\# T9281)

Loading dye (see recipe)

Tris-Glycine-SDS running buffer (see recipe)

Coomassie staining solution (Bio-Rad Cat\# 161-0786)

$60 \mathrm{~mm}$ cell culture dishes (Thermo Fisher Scientific Cat\# 150288)

Cell scrapers (Fisher Cat\# 11597692)

Gradient maker (Gradient Former Bio-Rad Cat\# 1654120)

16 x $18 \mathrm{~cm}$ sized gel electrophoresis system (Amersham Cat\# 80-6155-24)

Gel drying equipment (Fisher Scientific GD 2000 Gel Dryer System)

Additional reagents and equipment for centrifugations, protein concentration measurement and running of the gel.

\section{Notes before starting:}

- The cells should be grown in $60 \mathrm{~mm}$ plates. Cell confluency should be $75-90 \%$. One plate/sample provides enough proteins for one experiment. Enough plates should be made to ensure replicates.

- Prepare the gel the day before the experiment (see recipe for $12-20 \%$ acrylamide gradient gel).

- Preincubate the required volumes of labeling medium ( $2 \mathrm{ml} / \mathrm{plate}$ ) and the normal cell culture medium ( $5 \mathrm{ml} /$ plate) for at least 30 minutes in cell culture incubator (equilibrate to $5 \% \mathrm{CO}^{2}$ and $\left.37^{\circ} \mathrm{C}\right)$.

- During the labeling procedure, individual cell plates should be placed separately on the shelf of the incubator, not stacked on top of each other.

- For pulse experiments either anisomycin (reversible inhibitor of cytoplasmic translation) or emetine (irreversible inhibitor of cytoplasmic translation) can be used. For chase labeling only anisomycin is used.

- $\quad{ }^{35} \mathrm{~S}$ is harmful. Wear lab coat and gloves for protection. Avoid inhalation. Collect all the radioactive liquid and plastic produced during sample preparation. Put the radioactive waste in labeled sealed containers and hold for decay according to the institutional regulations.

\section{Protocol steps:}

1. Remove the culture media and immediately wash the cells twice with PBS. 
2. Incubate the cells for 30 minutes in labeling medium ( $2 \mathrm{ml} / 60 \mathrm{~mm}$ plate). During this time, $2 \mathrm{mg} / \mathrm{ml}$ of inhibitor of cytoplasmic protein translation can be prepared (anisomycin for pulse and chase labeling, emetine or anisomycin for pulse labeling).

3. Add the inhibitor of cytoplasmic protein translation to each plate $(100 \mu \mathrm{l} / 2 \mathrm{ml}$ of labeling medium, final concentration $100 \mu \mathrm{g} / \mathrm{ml}$ ) and incubate for minimum of $5 \mathrm{~min}$.

4. Add $400 \mu \mathrm{Ci}$ of ${ }^{35} \mathrm{~S}$-methionine or mixture of ${ }^{35} \mathrm{~S}$-methionine and ${ }^{35} \mathrm{~S}$-cysteine to each plate (final concentration $200 \mu \mathrm{Ci} / \mathrm{ml}$ ) and incubate for 15-60 minutes.

The labeling time can be adjusted based on the purpose of the analysis (see section Critical Parameters).

5. For pulse labeling, chase cells in the normal preincubated cell culture medium ( 5 $\mathrm{ml} / \mathrm{plate}$ ) for 10 minutes. For chase labeling, wash cells once with the normal preincubated cell culture medium and then chase the cells in the same medium (5 $\mathrm{ml} /$ plate) for 1-48 hours.

Chasing allows finishing the protein translation products in the pulse experiments, but is not always necessary, and enables the follow up of the stability of radioactively labeled proteins in the chase experiments. The chase time can also be adjusted based on the purpose of the analysis (see section Critical Parameters).

6. After the incubations, remove medium and wash the cells twice with PBS.

7. Scrape the cells in $4 \mathrm{ml}$ ice-cold PBS and transfer to $15 \mathrm{ml}$ falcon tube. Centrifuge the cells at $1000 \mathrm{~g}$ for 7 minutes at $+4{ }^{\circ} \mathrm{C}$.

Alternatively, trypsinize the cells. Samples can now be stored at $-80^{\circ} \mathrm{C}$.

8. Resuspend pellet in 50-200 $\mu$ ice-cold PBS with protease inhibitors. Adjust the volume of PBS according to the size of the cell pellet to get equal protein concentrations in the next step and keep on ice.

9. Determine the protein concentration by Bradford assay.

10. Take $30-60 \mu \mathrm{g}$ of protein from each sample and spin the proteins down at full speed $(13000 \mathrm{~g}-20000 \mathrm{~g})$ for 20 minutes at $4{ }^{\circ} \mathrm{C}$.

11. Resuspend the pellet in $33 \mu$ of $1 \times$ loading dye.

Samples should be kept at room temperature to avoid precipitation of SDS.

12. Sonicate the samples 2 times for 3 seconds with $50 \%$ intensity. 
13. Spin samples at full speed at room temperature, for 10-15 minutes, or until foam disappears.

To make sure that the samples are not getting warm, set the temperature of the centrifuge to $+22^{\circ} \mathrm{C}$. Samples can be also stored at $-80^{\circ} \mathrm{C}$.

14. Wash the wells of the $12-20 \%$ gradient polyacrylamide gel with $d_{d d} \mathrm{H}_{2} \mathrm{O}$, remove the water and fill the wells with running buffer.

15. Load the samples and run the gel with $10 \mathrm{~mA}$ and $100 \mathrm{~V}$ until the samples are inside the gel. Transfer the gel to cold room, if not already there, and run with $10 \mathrm{~mA}, 150 \mathrm{~V}$ until the blue loading dye line runs out of the gel (about $16 \mathrm{~h}$ ).

16. Place the gel on the Whatman filter paper, cover with plastic film and dry the gel $\left(65^{\circ} \mathrm{C}\right.$, under vacuum, for $1 \mathrm{~h}$ ).

17. Expose the dried gel to the phosphor screen by keeping the gel in phospholmager cassette ( 3 days is usually enough).

18. Image the screen.

19. Rehydrate the gel in $\mathrm{dd}_{2} \mathrm{O}$ on a gently rocking surface for one hour.

20. Stain the gel with coomassie on a gently rocking surface for one hour.

21. Wash the gel several times with $\mathrm{dd}_{2} \mathrm{O}$ on a gently rocking surface and leave the gel in $\mathrm{dd}_{2} \mathrm{O}$ overnight on the shaker.

22. Image the gel.

\section{ALTERNATE PROTOCOL 1 (optional)}

\section{IN ORGANELLO TRANSLATION ASSAY}

The translation rate and stability of the 13 mtDNA encoded proteins can also be studied in isolated mitochondria. This might be useful when the effects of non-mitochondrial factors should be excluded from the analysis. Only high quality functional mitochondria can be used for this experiment. The translation assay on isolated mitochondria is performed similarly as described above with some modifications.

\section{Materials}

Cultured adherent cells

PBS (Life Technologies Cat\# BE17-516F)

Mitochondrial isolation buffer (MIB, see recipe) 
Translation buffer (see recipe)

$150 \mathrm{~mm}$ cell plates (Thermo Fisher Scientific Cat\# 168381)

Dounce (glass-glass) homogenizer (volume for $10 \mathrm{ml}$ )

Rotary wheel

The rest of the materials and equipment are the same as for the in vivo mitochondrial translation assay.

\section{Notes before starting:}

- The cells should be grown on $150 \mathrm{~mm}$ plates. Cell confluency should be $75-90 \%$. One $150 \mathrm{~mm}$ plate/sample provides enough mitochondria for the experiment.

- Remember to be fast and efficient, but gentle at the same time. Mitochondria must be fully functional and able to respire during labeling!

- This protocol can also be used for mitochondria extracted from tissues. Check instructions for mitochondria isolation from different tissues from (Fernandez-Vizarra et al., 2010).

\section{Protocol steps:}

1. Remove the culture media and immediately wash the cells once with PBS.

2. Scrape the cells from the plates and pellet them at $1000 \mathrm{~g}$ for $7 \mathrm{~min}$ at $+4{ }^{\circ} \mathrm{C}$.

3. Wash the cell pellets with cold PBS and pellet the cells again.

4. Resuspend the cells in $10 \mathrm{ml}$ of MIB with BSA and homogenize the cells by 50 strokes with tight Dounce (glass-glass) homogenizer. Keep the homogenizer on ice during the whole homogenization step.

Different cell types might need optimization of the homogenization.

5. Centrifuge the samples at $1000 \mathrm{~g}$ for $5 \mathrm{~min}$ at $+4{ }^{\circ} \mathrm{C}$.

Unbroken cells end up in the pellet in this step.

6. Take the supernatant and centrifuge at $9000 \mathrm{~g}$ for $10 \mathrm{~min}$ to pellet down mitochondria.

7. Wash the mitochondria pellet with $5 \mathrm{ml}$ of MIB with BSA at $9000 \mathrm{~g}$ for $10 \mathrm{~min}$ at $+4{ }^{\circ} \mathrm{C}$.

8. Repeat step 7. 
9. Resuspend mitochondrial in $5 \mathrm{ml}$ isolation buffer without BSA.

10. Measure protein concentration using Bradford assay.

11. Pellet $2 \mathrm{mg}$ of the mitochondrial protein at $9500 \mathrm{~g}$ for $2 \mathrm{~min}$ at $+4{ }^{\circ} \mathrm{C}$.

Take $1 \mathrm{mg}$ of the mitochondrial protein if you need only pulse labeling.

12. Remove supernatant and resuspend in $2 \mathrm{ml}$ translation buffer.

13. Centrifuge at $9500 \mathrm{~g}$ for $2 \mathrm{~min}$ at $+4{ }^{\circ} \mathrm{C}$.

14. Resuspend pellet in $2 \mathrm{ml}$ translation buffer and add $30 \mu \mathrm{l}$ of ${ }^{35} \mathrm{~S}$-methionine.

15. Incubate $1 \mathrm{~h}$ at $37^{\circ} \mathrm{C}$ in a rotary wheel.

16. Centrifuge at $9500 \mathrm{~g}$ for $2 \mathrm{~min}$.

17. Resuspend pellet in $1 \mathrm{ml}$ translation buffer.

18. Split mitochondrial suspension into two tubes by pipetting $0.5 \mathrm{ml}$ to each tube. One of the tubes will be for pulse labeling and the other one is for chase labeling.

19. Centrifuge at $9500 \mathrm{~g}$ for $2 \mathrm{~min}$.

20. Tube 1 (pulse): resuspend pellet in $30 \mu$ l loading dye and leave at room temperature for $30 \mathrm{~min}$.

21. Tube 2 (chase): resuspend pellet in $650 \mu$ translation buffer with added cold methionine (final concentration $60 \mathrm{\mu g} / \mathrm{ml}$ ) and incubate three hours at $37^{\circ} \mathrm{C}$ in a rotary wheel.

22. Proceed with the steps $16-20$ for tube 2 .

Samples can now be stored at $-80^{\circ} \mathrm{C}$. 
23. The labeled mitochondrial proteins ( 150 to $300 \mathrm{mg}$ total protein/lane) are separated by SDS-PAGE as described in the previous protocol (steps $14-21$ ).

\section{ALTERNATE PROTOCOL 2 \\ NONRADIOACTIVE MITOCHONDRIAL TRANSLATION ASSAY}

The translation rate of the 13 mtDNA encoded proteins can also be studied with a nonradioactive method using the amino acid analog puromycin. Puromycin is a structural analog of tyrosyl-tRNA and it can enter the A-site of the ribosome incorporating into the newly synthetized proteins. Puromycin, however, causes premature chain release and thus its incorporation can be used only for evaluation of the translation rate. In the nonradioactive mitochondrial translation assay puromycin is used instead of radioactively labeled amino acids in the presence of emetine (a blocker of cytoplasmic translation) after which proteins are extracted from the cells and used for normal SDS-PAGE and western blotting followed by antibody based signal detection of puromycin.

\section{Materials}

Cultured adherent cells PBS (Life Technologies Cat\# BE17-516F)

Puromycin (Sigma Cat\# P8833)

Emetine (Sigma Cat\# E2375)

RIPA (see recipe)

Proteinase inhibitors (Thermo Scientific Cat\# 10137963)

Anti-Puromycin antibody (Millipore Cat\# MABE343, RRID:AB_2566826)

6-well plates (minimum) (Thermo Fisher Scientific Cat\# 140675)

Additional reagents and equipment for protein concentration measurement, sodium dodecyl sulfate polyacrylamide gel electrophoresis (SDS-PAGE) running, and immunoblotting.

\section{Notes before starting:}

- The cells are grown in 6-well plates. Cell confluency should be 75-90\%. Each well from 6well plate provides enough proteins for the experiment.

\section{Protocol steps}

1. Change fresh media to the cells.

2. Preincubate cells with $100 \mu \mathrm{g} / \mathrm{ml}$ of emetine for $10 \mathrm{~min}$. 
3. Add $10 \mu \mathrm{g} / \mathrm{ml}$ of puromycin and incubate $20 \mathrm{~min}$.

Different cell lines might need optimization of the incubation time with puromycin.

It is good to include two samples as negative controls. One, which in addition to emetine has $100 \mu \mathrm{g} / \mathrm{ml}$ of chloramphenicol at step 2. Another one without puromycin at step 3.

4. Wash the cells once with PBS.

5. Scrape the cells into ice cold PBS and pellet the cells at $1000 \mathrm{~g} 10 \mathrm{~min}$ at $+4{ }^{\circ} \mathrm{C}$.

\section{Samples can now be stored at $-80^{\circ} \mathrm{C}$.}

6. Resuspend the cell pellets in $1 \times$ RIPA with proteinase inhibitors and incubate on ice for $10 \mathrm{~min}$.

7. Centrifuge the samples at $14000 \mathrm{~g}$ for $10 \mathrm{~min}$ at $+4{ }^{\circ} \mathrm{C}$.

8. Take supernatant to a new tube and measure protein concentration using Bradford assay.

\section{Samples can now be stored at $-80^{\circ} \mathrm{C}$.}

9. Run samples on SDS-PAGE. Use $30 \mu \mathrm{g}$ of protein for each sample.

10. Transfer the gel to PVDF or nitrocellulose membrane by manufacturer's instructions.

11. Block the membrane with $5 \%$ milk in TBST for $1 \mathrm{~h}$.

12. Wash the membrane on a shaker 5 min three times in $1 \times$ TBST to remove traces of milk before adding the antibody.

13. Incubate the membrane with anti-puromycin antibody $(1: 25000$ in the case of the suggested antibody) in $1 \%$ BSA/TBST on a shaker over night at $+4{ }^{\circ} \mathrm{C}$.

14. Wash the membrane three times for 15 min each with $1 \times$ TBST on a shaker.

15. Incubate the membrane with the secondary antibody in 1\% BSA/TBST (according to manufacturer's instructions) for at least $1 \mathrm{~h}$ at room temperature on a shaker.

16. Wash the membrane three times for 10 min each with 1 XTBST on a shaker.

17. Image protein bands using a chemiluminescence detection kit according to the manufacturer's instructions and repeat the steps 13 - 17 with a loading control antibody. 


\section{BASIC PROTOCOL 2}

\section{BLUE NATIVE POLYACRYLAMIDE GEL ELECTROPHORESIS (BN-PAGE)}

BN-PAGE enables to separate intact protein complexes and can be used to study assembly of mitochondrial protein complexes. In this method mitochondria are extracted from cells using digitonin, which brakes the outer membrane of the cells. Isolated mitochondria are treated with lauryl maltoside, which releases the OXPHOS complexes from the mitochondrial membranes.

\section{Materials}

Chloramphenicol (see recipe)

PBS (Life Technologies Cat\# BE17-516F)

Protease inhibitors (Thermo Scientific Cat\# 10137963)

Digitonin (see recipe)

Lauryl maltoside ( $n$-Dodecyl $\beta$-D-maltoside) (Sigma Cat\# D4641)

MB2 buffer (see recipe)

Blue Native loading dye (see recipe)

$3 \times$ Gel buffer (see recipe)

40\% Acrylamide/Bis 37.5:1 (Bio-Rad Cat\# 161-0148)

$\mathrm{ddH} \mathrm{H}_{2} \mathrm{O}$

$100 \%$ Glycerol (Sigma Cat\# G5516)

Ammonium persulfate (prepare fresh)

$\mathrm{N}, \mathrm{N}, \mathrm{N}^{\prime}, \mathrm{N}^{\prime}$-Tetramethylethylenediamine (TEMED) (Sigma Cat\# T9281)

Cathode buffer (see recipe)

Blue cathode buffer (see recipe)

Anode buffer (see recipe)

Antibodies against respiratory chain complexes. For example, Complex I (NDUFA9, Abcam Cat\# ab14713, RRID:AB_301431), Complex II (SDHA, Abcam Cat\# ab14715, RRID:AB_301433),

Complex III (UQCRC2, Abcam Cat\# ab14745, RRID:AB_2213640) and Complex IV (MTCOI, Abcam Cat\# ab14705, RRID:AB_2084810).

$100 \mathrm{~mm}$ cell plates (Thermo Fisher Scientific Cat\# 130182)

Additional equipment for protein concentration measurement, gel running, and immunoblotting.

\section{Notes before starting}

- The cells are grown on $100 \mathrm{~mm}$ plates. Cell confluency should be $80-90 \%$. One $100 \mathrm{~mm}$ plate/sample provides enough proteins for the experiment. 
- Perform all the steps at $+4{ }^{\circ} \mathrm{C}$ and do not vortex.

\section{Protocol steps}

\section{Sample preparation}

1. Wash the cells once with ice cold PBS.

2. Scrape the cells and pellet them at $1000 \mathrm{~g}$ for $10 \mathrm{~min}$ at $+4{ }^{\circ} \mathrm{C}$.

3. Resuspend the cells in $1 \mathrm{ml}$ ice cold PBS with protease inhibitor.

4. Pellet the cells at $1000 \mathrm{~g}$ for $10 \mathrm{~min}$ (use $2 \mathrm{ml}$ Eppendorf tubes).

5. Resuspend the cells in $1 \mathrm{ml}$ PBS with protease inhibitors.

6. Measure protein concentration with Bradford method.

7. Pellet the cells at $1000 \mathrm{~g}$ for $10 \mathrm{~min}$ at $+4{ }^{\circ} \mathrm{C}$.

8. Resuspend the cells in PBS with protease inhibitor to a final concentration of $5 \mathrm{mg} / \mathrm{ml}$.

9. Add $4 \mathrm{mg} / \mathrm{ml}$ digitonin to final concentration of $2 \mathrm{mg} / \mathrm{ml}$. Mix well and incubate on ice for $5 \mathrm{~min}$.

The concentration of digitonin/cell type might need optimization. Digitonin is a mild detergent and brakes the cell membrane freeing mitochondria into the solution.

10. Add PBS with proteinase inhibitor to final volume of $1.5 \mathrm{ml}$.

11. Centrifuge at $10000 \mathrm{~g}$ for $10 \mathrm{~min}$ at $+4{ }^{\circ} \mathrm{C}$.

In this step mitochondria are pelleted.

12. Resuspend the pellets in MB2 buffer. The volume of MB2 is half of the volume of PBS in step 8.

13. Add $10 \%$ lauryl maltoside to final concentration of $1 \%$. Incubate on ice for $15 \mathrm{~min}$ (this step can be longer up to a couple of hours).

Lauryl maltoside brakes mitochondrial membranes and releases OXPHOS complexes in the solution.

14. Centrifuge at $20000 \mathrm{~g}$ for $20 \mathrm{~min}$ at $+4{ }^{\circ} \mathrm{C}$.

15. Put the supernatant into a new Eppendorf tube and measure protein concentration.

16. Add loading dye, a volume that is half of the volume of lauryl maltoside used in step 13. 


\section{Samples can now be stored at $-80^{\circ} \mathrm{C}$.}

\section{Gel electrophoresis}

1. Prepare 6-15\% separating gel with gradient gel mixer according to the table in the reagents and solutions section.

2. After polymerization of the separating gel wash it with $1 \times \mathrm{GB}$.

3. Prepare stacking gel mixture according to table in the reagents and solutions section, insert comb and fill up to the top with stacking gel mixture.

4. After polymerization of the stacking gel remove the comb and wash the wells with $1 \mathrm{x}$ GB.

5. Fill the gel cassette with the blue cathode buffer until the bottom of the wells and fill the wells with the blue cathode buffer. Loading of the samples is easier when the cassette is not filled to the top.

6. Load the samples (5-30 $\mathrm{ug}$ of protein) into wells.

7. Fill the gel cassette to the top with the blue cathode buffer and the tank with anode buffer.

8. Run the gel for $15 \mathrm{~min}$ at $40 \mathrm{~V}$, then increase to $80 \mathrm{~V}$ (or $6 \mathrm{mAmp}$, do not exceed 10 $\mathrm{mAmp}$ ) until the dye reaches to $2 / 3$ of the gel.

9. Replace the blue cathode with cathode buffer and continue electrophoresis until the dye front is run out. The gel run takes about $4 \mathrm{~h}$.

10. Continue with the protein transfer, blocking and antibody incubation as in the steps $10-$ 17 for the nonradioactive mitochondrial translation assay. Use the primary antibodies against OXPHOS complexes sequentially.

\section{ALTERNATE PROTOCOL 2 (optional)}

\section{SDS-PAGE OF OXPHOS COMPLEX SUBUNIT RECOVERY UNDER A SPECIFIC TREATMENT}

In addition to studying the entire OXPHOS complexes by BN-PAGE, the individual subunits of OXPHOS complexes can also be investigated by SDS-PAGE. If either PAGE is done to evaluate the effects of a stress treatment, it may be useful to deplete OXPHOS subunits first by pretreating the cells with $30-40 \mu \mathrm{g} / \mathrm{ml}$ of chloramphenicol for $48 \mathrm{~h}$, because the OXPHOS complexes and subunits can be stable in cultured cells up to $48 \mathrm{~h}$. Following the pretreatment, the recovery of the complexes can be followed and compared between treated and nontreated cells. See for example Fig. 4 in Konovalova et al. for the effects on recovery after canavanine treatment.

\section{Materials}


Chloramphenicol (see recipe)

\section{REAGENTS AND SOLUTIONS}

\section{Inhibitors of cytoplasmic translation}

$2 \mathrm{mg} / \mathrm{ml}$ of either emetine (Sigma Cat\# E2375) (for pulse labeling) or anisomycin (Sigma Cat\# A9789) (reversible, for pulse and chase labeling) in PBS. Filter sterilize. Prepared fresh prior to use.

\section{$2 \times$ loading dye (in vivo and in organello mitochondrial translation assay)}

186 mM Tris- $\mathrm{HCl}$, pH 6.7-6.8 (Tris base (Fisher BioReagents Cat\# BP152))

$15 \%$ glycerol (Sigma Cat\# G5516)

2\% SDS (Fisher Cat\# 10607443)

$0.5 \mathrm{mg} / \mathrm{ml}$ bromophenol blue (Sigma Cat\# B5525)

The $2 \times$ loading dye can be stored up to one year without $\beta$-mercaptoethanol at $-20^{\circ} \mathrm{C}$. Prepare fresh $1 \times$ loading dye just prior the sample run using $2 \times$ loading dye and $\mathrm{dd}_{2} \mathrm{O}$. Add $\beta$-mercaptoethanol to final concentration of $6 \%$ to the $1 \times$ loading dye. For example, to prepare $500 \mu \mathrm{l}$ ready to use loading dye take $250 \mu \mathrm{l} 2$ x loading dye add $220 \mu \mathrm{ldd \textrm {H } _ { 2 }} 0$ and $30 \mu \mathrm{l} \beta$-mercaptoethanol.

\section{2-20\% Acrylamide gradient gel}

\begin{tabular}{llll}
\hline & Resolving gel 12\% & Resolving gel 20\% & Stacking gel \\
\hline $40 \%$ Acrylamide-Bis 37:1 & $3.6 \mathrm{ml}$ & $6.2 \mathrm{ml}$ & $1.5 \mathrm{ml}$ \\
$1.5 \mathrm{M}$ Tris- $\mathrm{HCl} \mathrm{pH} 8.8$ & $3 \mathrm{ml}$ & $3 \mathrm{ml}$ & - \\
$1 \mathrm{M}$ Tris- $\mathrm{HCl} \mathrm{pH} \mathrm{6.8}$ & - & - & $2.5 \mathrm{ml}$ \\
$\mathrm{ddH} \mathrm{H}_{2} \mathrm{Ol}$ & $4.2 \mathrm{ml}$ & $1.6 \mathrm{ml}$ & $6 \mathrm{ml}$ \\
$100 \%$ glycerol & $1.2 \mathrm{ml}$ & $1.2 \mathrm{ml}$ & - \\
$20 \%$ SDS & $60 \mu \mathrm{l}$ & $60 \mu \mathrm{l}$ & $50 \mu \mathrm{l}$ \\
$10 \%$ Ammonium persulfate & $60 \mu \mathrm{l}$ & $36 \mu \mathrm{l}$ & $100 \mu \mathrm{l}$ \\
TEMED & $7 \mu \mathrm{l}$ & $4.8 \mu \mathrm{l}$ & $10 \mu \mathrm{l}$ \\
\hline
\end{tabular}

Keep mixtures on ice and use fresh. Add SDS (forms bubbles), APS and TEMED (they start the polymerization) last. Mix gently avoiding air bubbles. Do not vortex. Use $9.2 \mathrm{ml}$ of $12 \%$ and $9.7 \mathrm{ml}$ of $20 \%$ gel to the gradient gel mixer for one $16 \times 18 \mathrm{~cm}$ sized gel. The ready gel can be stored at $+4{ }^{\circ} \mathrm{C}$ for up to $2-3$ days. 


\section{5 x Tris-Glycine-SDS running buffer}

$15 \mathrm{~g}$ Tris base (Fisher Bioreagents Cat\# BP152)

72 g Glycine (Thermo Scientific Cat\# G/P460/53)

3 g SDS (Fisher Cat\# 10607443)

Fill up to 1 liter with ddH $\mathrm{H}_{2} \mathrm{O} .5 \mathrm{x}$ Tris-Glycine-SDS running buffer can be stored at $+4{ }^{\circ} \mathrm{C}$ up to one year. Using $\mathrm{ddH}_{2} \mathrm{O}$ prepare $1 \mathrm{x}$ Tris-Glycine-SDS running buffer prior to use.

\section{Mitochondrial isolation buffer (MIB, in organello mitochondrial translation assay)}

320 mM sucrose (Sigma Cat\# S7903)

1 mM EDTA (Life Technologies Cat\# 15575-038)

$10 \mathrm{mM}$ Tris- $\mathrm{HCl}$ (Tris base (Fisher Bioreagents Cat\# BP152))

Adjust $\mathrm{pH}$ to 7.4. Can be stored at $+4{ }^{\circ} \mathrm{C}$ for one week. Prepare MIB without BSA and with BSA (BioWest Cat\# P6154) $(1 \mathrm{mg} / \mathrm{ml})$.

\section{Translation buffer (in organello mitochondrial translation assay)}

\begin{tabular}{lll}
\hline & Volume & Final concentration \\
\hline 2 x translation mix & $5 \mathrm{ml}$ & \\
Amino acids $(6 \mathrm{mg} / \mathrm{ml}$ each) & $100 \mu \mathrm{l}$ & $60 \mu \mathrm{g} / \mathrm{ml}$ \\
$200 \mathrm{mM}$ ATP & $250 \mu \mathrm{l}$ & $5 \mathrm{mM}$ \\
$50 \mathrm{mM} \mathrm{GTP}$ & $40 \mu \mathrm{l}$ & $20 \mu \mathrm{M}$ \\
$1 \mathrm{M} \mathrm{creatine} \mathrm{phosphate}$ & $60 \mu \mathrm{l}$ & $6 \mathrm{mM}$ \\
$10 \mathrm{mg} / \mathrm{ml}$ creatine kinase & $60 \mu \mathrm{l}$ & $60 \mu \mathrm{g} / \mathrm{ml}$ \\
Cysteine $(6 \mathrm{mg} / \mathrm{ml})$ & $100 \mu \mathrm{l}$ & $60 \mu \mathrm{g} / \mathrm{ml}$ \\
Tyrosine $(3 \mathrm{mg} / \mathrm{ml})$ & $200 \mu \mathrm{l}$ & $60 \mu \mathrm{g} / \mathrm{ml}$ \\
dd $\mathrm{H}_{2} \mathrm{O}$ & $4.595 \mathrm{ml}$ & \\
\hline Total volume & $10 \mathrm{ml}$ &
\end{tabular}

Do not add cysteine to translation buffer in case of using ${ }^{35} \mathrm{~S}$-mehionine and ${ }^{35} \mathrm{~S}$-cysteine mixture.

Always prepare fresh 200 mM ATP: $60.5 \mathrm{mg}$ ATP in $485 \mu \mathrm{lddH_{2 }}$, add $15 \mu \mathrm{l} 10 \mathrm{M} \mathrm{KOH}$ to adjust $\mathrm{pH}$ to 7.0 .

Always prepare fresh $50 \mathrm{mM}$ GTP: $2.8 \mathrm{mg}$ in $100 \mu \mathrm{ldd} \mathrm{H}_{2} \mathrm{O}$.

\section{$2 \times$ translation mix for translation buffer}


200 mM mannitol (Sigma Cat\# M9647)

$20 \mathrm{mM}$ sodium succinate (Sigma Cat\# S2378)

$160 \mathrm{mM} \mathrm{KCl}$ (Sigma Cat\# P9333)

$10 \mathrm{mM} \mathrm{MgCl}_{2}$ (Amresco Cat\# 7791-18-6)

2 mM KPi (Sigma Cat\# P5655)

50 mM HEPES (Life Technologies Cat\# 15630049)

Adjust $\mathrm{pH}$ to 7.4 . Can be stored at $-20^{\circ} \mathrm{C}$ for several months.

\section{Chloramphenicol}

$1 \mathrm{mg} / \mathrm{ml}$ of chloramphenicol (Sigma Cat\# C3175) in basic medium (DMEM) without serum and other additional components. Add warm medium to the powder and incubate at $37^{\circ} \mathrm{C}$ until the powder dissolves. Filter sterilize. Can be stored at $4{ }^{\circ} \mathrm{C}$ for one week.

\section{$1 \times R I P A$}

$20 \mathrm{mM}$ Tris- $\mathrm{HCl}$ pH 7.5 (Tris base (Fisher BioReagents Cat\# BP152))

$150 \mathrm{mM} \mathrm{NaCl}$ (Fisher BioReagents Cat\# BP358)

$1 \mathrm{mM} \mathrm{Na}{ }_{2}$ EDTA

1 mM EGTA (Sigma Cat\# E4378)

1\% NP-40 (Fluka BioChemika Cat\# 74385)

$1 \%$ sodium deoxycholate (Sigma Cat\# 30970)

$2.5 \mathrm{mM}$ sodium pyrophosphate

$1 \mathrm{mM} \beta$-glycerophosphate (Sigma Cat\# G9422)

$1 \mathrm{mM} \mathrm{Na}_{3} \mathrm{VO}_{4}$ (Sigma Cat\# S6508)

Can be stored at $-20^{\circ} \mathrm{C}$ up to one year. Alternatively, commercial RIPA lysis buffer can be used (Cell Signaling Technology, 9806S).

\section{Digitonin}

Note: Digitonin is toxic! Be cautious and use face mask and other protection! Dissolve 4 $\mathrm{mg} / \mathrm{ml}$ digitonin (Sigma Cat\# D141) in PBS (Life Technologies Cat\# BE17-516F) at $100{ }^{\circ} \mathrm{C}$ until no precipitate is visible and cool on ice immediately. Add protease inhibitor. Use fresh.

\section{3x Gel buffer (3 x GB)}

$1.5 \mathrm{M}$ aminocaproic acid (Sigma Cat\# A2504)

150 mM Bis-tris (Sigma Cat\# B7535)

Adjust $\mathrm{pH}$ to 7.0. Can be stored at $+4^{\circ} \mathrm{C}$ up to one year. 


\section{BN-PAGE gel}

\begin{tabular}{llll}
\hline & $\begin{array}{l}\text { Separating 6\% } \\
\text { gel }\end{array}$ & $\begin{array}{l}\text { Separating 15\% } \\
\text { gel }\end{array}$ & $\begin{array}{l}\text { Stacking 4\% } \\
\text { gel }\end{array}$ \\
\hline $3 \times \mathrm{GB}$ & $3.3 \mathrm{ml}$ & $3.3 \mathrm{ml}$ & $1.64 \mathrm{ml}$ \\
$40 \%$ Acrylamide/Bis $37.5: 1$ & $1.5 \mathrm{ml}$ & $3.75 \mathrm{ml}$ & $0.5 \mathrm{ml}$ \\
$\mathrm{ddH}_{2} \mathrm{O}$ & $5.14 \mathrm{ml}$ & $0.9 \mathrm{ml}$ & $2.8 \mathrm{ml}$ \\
$100 \%$ Glycerol & 0 & 2 & 0 \\
$10 \%$ Ammonium persulfate & $60 \mu \mathrm{l}$ & $10 \mu \mathrm{l}$ & $60 \mu \mathrm{l}$ \\
TEMED & $4 \mu \mathrm{l}$ & $2 \mu \mathrm{l}$ & $6 \mu \mathrm{l}$ \\
\hline
\end{tabular}

Keep mixtures on ice and use fresh. Add APS and TEMED (they start polymerization) last. Mix gently avoiding air bubbles. Use $2.6 \mathrm{ml}$ of $6 \%$ gel and $2.1 \mathrm{ml} \mathrm{15 \%} \mathrm{gel} \mathrm{to} \mathrm{the} \mathrm{gradient}$ gel mixer for one $8.3 \times 7.3 \mathrm{~cm}$ sized gel. From the recipe above at least three gels can be casted.

\section{Cathode buffer}

15 mM Bis-tris (Sigma Cat\# B7535)

$50 \mathrm{mM}$ Tricine (Sigma Cat\# T9784)

Adjust $\mathrm{pH}$ to 7.0. Can be stored at $+4{ }^{\circ} \mathrm{C}$ up to one year.

\section{Blue cathode buffer}

Add 0.02\% Serva Blue G (Serva Cat\# 35050) to cathode buffer.

Can be stored at $+4{ }^{\circ} \mathrm{C}$ up to one year.

Anode buffer

50 mM Bis-tris (Sigma Cat\# B7535)

Adjust $\mathrm{pH}$ to 7.0. Can be stored at $+4{ }^{\circ} \mathrm{C}$ up to one year.

\section{MB2 buffer}

1 M Aminocaproic acid (Sigma Cat\# A2504)

2 mM EDTA (Life Technologies Cat\# 15575-038)

Use $3 \times$ GB to adjust the volume. Can be stored at $+4{ }^{\circ} \mathrm{C}$ up to one year.

\section{Loading dye for BN-PAGE}


750 mM Aminocaproic acid (Sigma Cat\# A2504)

5\% Serva Blue G (Serva Cat\# 35050)

Can be stored at room temperature up to one year.

\section{COMMENTARY}

\section{Background Information}

The simplest method to study the steady state level of mtDNA-encoded proteins is the basic SDS-PAGE followed by western blotting. However, western blotting allows to study only individual OXPHOS subunits, which requires specific antibodies and is time-consuming. In addition, the stability and the translation rate of entire complexes and of individual proteins cannot be studied using western blotting. The mitochondrial translation assays enable the evaluation of the stability and the translation rate of all the 13 mtDNA encoded proteins at the same time. The BN-PAGE allows to evaluate the assembly of OXPHOS subunits and when BNPAGE is applied after depletion of mtDNA-encoded proteins the assemble rate of the entire complexes can be studied. Thus, here we described the methods allowing the study of mitochondrial translational processes and assembly of OXPHOS subunits.

\section{Critical Parameters and Troubleshooting}

In our laboratory human osteosarcoma cells (143B), embryonic kidney cells (HEK293), neuroblastoma cells (SH-SY5Y), and primary myoblasts and myotubes have been successfully used for all of the protocols. Each protocol is adjustable to also other cell types. The in organello mitochondrial translation assay and BN-PAGE are adjustable also to different tissue samples. Different cell and tissue types might need, however, some optimization of the different steps in the protocols, such as the sufficient amount of cells, the length of chloramphenicol treatment or the method of homogenization.

In the mitochondrial translation assays, the pulse and chase times can vary depending on the purpose of the study. When studying protein translation rate, short pulse labeling time (15-45 $\mathrm{min}$ ) without chase is recommended. When the stability of the proteins is to be studied, several different chase time points are usually required ( $2 \mathrm{~h}$ and more). The pattern of the labeled proteins in the gel is usually constant between different cell types, but small changes in the abundance and migration of individual proteins might be seen.

For the in organello mitochondrial translation assay, the mitochondrial extraction is the most critical step of the protocol. Because mitochondria need to be metabolically active for the labeling step, the extraction must be done fast and efficiently, but at the same time gently enough. Thus, the homogenization step should be optimized for different cell types. One important step of the extraction is the washing of the mitochondrial pellet to discard contaminations from the cytoplasm. It is also important to keep the mitochondria well oxygenated throughout the labeling procedure, which can be assured by using the rotary wheel. 
The frequent problem with the radioactive translation methods is a low signal. In this case, the fresh radioactive label of sufficient amount should be used. In case of high background, the correct handling of the samples (especially the temperature) should be checked.

For the BN-PAGE the most critical part of the protocol is the handling of the cells and the extraction of the mitochondrial proteins. Different cell types might need some adjustment of cell to detergent ratios.

\section{Understanding Results}

The radioactive translation assay enables visual detection of all the $13 \mathrm{mtDNA}$ encoded proteins within one assay (Figure 1A). Pulse labeling allows to evaluate the rate of mitochondrial translation, whereas the chase labeling enables to investigate whether the stability of the newly synthesized proteins is affected. The normalization of the results to the amount of total loaded protein can be done by coomassie staining of the gel. The band intensity of mitochondrial proteins can be quantified separately or all together.

With the nonradioactive translation assay only the translation rate in general, not the rate or stability of individual proteins, can be detected. For quantification analysis the immunoblot signal of puromycin should be normalized to a loading control (any housekeeping protein such as GAPDH or $\beta$-tubulin).

The BN-PAGE allows the evaluation of intact OXPHOS complexes (Figure 1B). The molecular weights of the complexes are about $1000 \mathrm{kDa}$ (complex I, Cl), $600 \mathrm{kDa}$ (complex V, CV), $500 \mathrm{kDa}$ (complex III, CIII), $200 \mathrm{kDa}$ (complex IV, CIV) and $130 \mathrm{kDa}$ (complex II, CII). In addition, the complexes exist in higher-order supercomplexes, of which some might be detected with the described method. Typically, no good loading controls are available for BN-PAGE, which puts emphasis on equal loading of protein and repeated experiments. Also, of the five OXPHOS complexes, only complexes I, III, IV and V contain subunits encoded by mtDNA, whereas complex II is entirely encoded by nuclear genes. Therefore, if mitochondrial protein synthesis is blocked, decreases may be seen in the amounts of $\mathrm{Cl}$, or $\mathrm{CIII-CV}$, but the amount of Cll should not decrease. Instead CIl amount may even increase if the cell initiates a mitochondrial biogenesis program to compensate for the functional defect. Thus, quantifying the ratios of the amounts of the other complexes to complex II may be useful. In addition, if a decrease in the amount of one complex is suspected, the individual subunits of that complex can be quantified by SDS-PAGE against housekeeping proteins and proteins indicating mitochondrial mass such as porin.

\section{Time Considerations}

For the in vivo and in organello translation assays, cells must be plated one day before the labeling. The labeling of the cells and the preparation of the samples takes one day for pulse experiment and one to two days for chase experiment. We recommend preparing the gel the day before the running of the samples. The running of the gel takes about 16 hours and can be 
done overnight. Next day the gel is dried and exposed to the phosphor screen for one to five days depending on the freshness of the label and the amount of the protein in the gel. The gel can be stained with coomassie after imaging and the washing of the gel takes one day. Thus, the total time is about seven working days.

In the nonradioactive mitochondrial translation assay, the cells must be plated one day before the actual experiment. The protein extraction, gel running and immunoblotting takes three days. Altogether, the whole experiment takes four days.

In the BN-PAGE cells must be plated one day before the actual experiment. We recommend preparing the gel and the buffers the day before PAGE. The protein extraction takes half a day and the gel running and western blotting one whole day. The immunoblotting with five OXPHOS complex antibodies sequentially takes five days. Altogether, the entire experiment takes about 8 working days.

\section{LITERATURE CITED}

D'Amico, D., Sorrentino, V. and Auwerx, J. 2017. Cytosolic Proteostasis Networks of the Mitochondrial Stress Response. Trends Biochem. Sci. 42:712-725.

Fernandez-Silva, P., Acin-Perez, R., Fernandez-Vizarra, E., Perez-Martos, A. and Enriquez, J.A. 2007. In vivo and in organello analyses of mitochondrial translation. Methods Cell Biol. 80:571588.

Fernandez-Vizarra, E., Ferrin, G., Perez-Martos, A., Fernandez-Silva, P., Zeviani, M. and Enriquez, J.A. 2010. Isolation of mitochondria for biogenetical studies: An update. Mitochondrion 10:253262.

Hallberg, B.M. and Larsson, N.G. 2014. Making proteins in the powerhouse. Cell Metab. 20:226240.

Hilander, T., Zhou, X.L., Konovalova, S., Zhang, F.P., Euro, L., Chilov, D., Poutanen, M., Chihade, J., Wang, E.D. and Tyynismaa, H. 2018. Editing activity for eliminating mischarged tRNAs is essential in mammalian mitochondria. Nucleic Acids Res. 46:849-860.

Konovalova, S., Hilander, T., Loayza-Puch, F., Rooijers, K., Agami, R. and Tyynismaa, H. 2015. Exposure to arginine analog canavanine induces aberrant mitochondrial translation products, mitoribosome stalling, and instability of the mitochondrial proteome. Int. J. Biochem. Cell Biol. 65:268-274.

Miyamoto-Sato, E., Nemoto, N., Kobayashi, K. and Yanagawa, H. 2000. Specific bonding of puromycin to full-length protein at the C-terminus. Nucleic Acids Res. 28:1176-1182.

Moullan, N., Mouchiroud, L., Wang, X., Ryu, D., Williams, E.G., Mottis, A., Jovaisaite, V., Frochaux, M.V., Quiros, P.M., Deplancke, B., Houtkooper, R.H. and Auwerx, J. 2015. 
Tetracyclines Disturb Mitochondrial Function across Eukaryotic Models: A Call for Caution in Biomedical Research. Cell Rep. 10:1681-1691.

Nunnari, J. and Suomalainen, A. 2012. Mitochondria: in sickness and in health. Cell 148:11451159.

Schmidt, E.K., Clavarino, G., Ceppi, M. and Pierre, P. 2009. SUnSET, a nonradioactive method to monitor protein synthesis. Nat. Methods 6: 275-277.

\section{FIGURE LEGENDS}

\section{Figure 1.}

A) In vivo mitochondrial translation assay in monkey kidney cells (COS-7). Newly synthesized mitochondrial proteins were pulse $(1 \mathrm{~h})$ or chase $\left(27 \mathrm{~h}\right.$ ) labeled with $\left[{ }^{35} \mathrm{~S}\right]$ in control cells (Ctrl) or in cells treated with an arginine analog, canavanine (CAN). The $13 \mathrm{mtDNA}$-encoded proteins that are radioactively labeled are marked in the gel image. ND4 and ATP8 subunits appear as a single band. Coomassie staining is shown to allow comparison of protein loading. Pulse labeling shows that canavanine treatment induced aberrantly sized polypeptides in the proximity of COX2/COX3 subunits (marked with asterisks). Chase labeling reveals reduced stability of mtDNA-encoded proteins in canavanine treated cells.

B) Immunoblot of BN-PAGE of OXPHOS complexes isolated from HEK293 cells. Complexes I to IV were detected using antibodies to the indicated complex subunits. 